ISSN: 02162938

\title{
MENINGKATAN TANGGUNG JAWAB BELAJAR DARING DENGAN MENERAPAN LAYANAN KONSELING INDIVIDU MENGGUNAKAN TEKNIK SELF-MANAGEMENT
}

\author{
Kusumaningtyas Febri Wijayanti \\ SMK PGRI 2 Jombang \\ kusumaningtyas05@gmail.com
}

\author{
Anita Dianasari \\ SMK Negeri 1 Kemlagi \\ anitadianasari@gmail.com
}

\begin{abstract}
Abstrak
Pada zaman sekarang ini pendidikan di Indonesia sedang berusaha mencapai mutu pendidikan yang baik. Agar mutu pendidikan yang baik dapat tercapai, maka peserta didik harus belajar dengan tekun karena tanggung jawab seorang peserta didik adalah belajar. Apabila permasalahan tersebut tidak segera diatasi maka akan berdampak pada hasil belajar peserta didik. Strategi yang bisa dilakukan untuk mengatasi adalah dengan menggunakan konseling individu teknik self-management. Tujuan dari penelitian ini adalah untuk mengetahui sejauh mana tanggung jawab belajar daring peserta didik dengan menggunakan layanan konseling individu dengan teknik self-management pada siswa kelas XII TKJ di SMK PGRI 2 Jombang. Penelitian ini menggunakan jenis penelitian kualitatif desain Penelitian Tindakan Bimbingan dan Konseling. Penelitian ini dilakukan 2 siklus yaitu siklus I dan siklus II. Teknik pengumpulan data menggunakan wawancara, observasi, dan skala pengukuran. Hasil dari siklus I 30\% dengan katagori rendah sedangkan siklus II meningkat menjadi 70\% dengan katagori sedang. Hal ini berarti Strategi self-management dapat meningkatkan tanggung jawab belajar daring peserta didik.
\end{abstract}

Kata Kunci: Tanggung Jawab belajar Daring, Teknik Self-Management

\begin{abstract}
This new era, Indonesian education tries to be good quality. In order to catch good quality of education, so the students must study hardly because it is their responsibility. If this problem is not fixed soon, so the result study of the student will get impact. The strategy that can be done this problem is an individual counseling self-management technique. The aims of this research is to know how far the responsibility of student when they do online class with an individual counseling self-management at student XII grade TKJ SMK PGRI 2 Jombang. The kind of this research is qualitative research with Counselor and Guidance Action research design. This research is done in two cycles, first cycle and second cycle. The data collection is used interview, observation, and measurement scale. The result of first cycle $30 \%$ low category, but second cycle rises to be $70 \%$ middle category. It means that self-management strategy can increase student's responsibility during online class.
\end{abstract}

Keywords: Responsibility, online class, self-management technique 
Jurnal HELPER, Vol 36 No 1 (2019) 07 - 15

Bimbingan dan Konseling Universitas PGRI Adi Buana Surabaya

ISSN: 02162938

\section{LATAR BELAKANG}

Tanggung jawab belajar merupakan kesadaran siwa dalam melaksanakan proses pembelajaran baik secara lisan maupun tulisan,baik secara Daring (Dalam Jaringan) maupun Luring (Luar Jaringan), memiliki komitmen terhadap tugas, melaksanakan kebiasaan selama belajar, mampu melaksanakan tugas secara mandiri. Semua itu akan membantu peserta didik memahami materi dan melaksanakan perintah dari bapak/ibu guru dengan sebaik-baiknya. Menurut Lewis (Dewi, 2016) “tanggung jawab belajar adalah kesediaan seseorang untuk mengerjakan tugas belajar dengan sebaikbaiknya dalam segala konsekuensi yang menyertainya”.

Peserta didik yang sadar pada tugas adalah peserta didik yang mandiri, disiplin dan tanggung jawab. Tugas yang diberikan kepada peserta didik harus dikerjakan dengan kesadaran akan kewajiban. Kesadaran akan kewajiban merupakan salah satu pengertian dari tanggung jawab. Tanggung jawab adalah sikap dan perilaku seseorang untuk melaksanakan tugas dan kewajibannya, yang seharusnya di lakukan, terhadap diri sendiri, masyarakat, lingkungan (alam, sosial, dan budaya), negara dan Allah Yang Maha Esa (Fadillah \& Khorida, 2013:205).

Peserta didik yang sadar pada tugas adalah peserta didik yang mandiri, disiplin dan tanggung jawab. Tugas yang diberikan kepada peserta didik harus dikerjakan dengan kesadaran akan kewajiban. Kesadaran akan kewajiban merupakan salah satu pengertian dari tanggung jawab. Tanggung jawab adalah sikap dan perilaku seseorang untuk melaksanakan tugas dan kewajibannya, yang seharusnya di lakukan, terhadap diri sendiri, masyarakat, lingkungan (alam, sosial, dan budaya), negara dan Allah Yang Maha Esa (Fadillah \& Khorida, 2013:205).

Permasalahan di atas jika tidak segera diselesaikan maka akan berdampak pada nilai hasil belajar siswa. Berdasarkan hasil pengamatan, peneliti akan menggunakan konseling individu dengan menggunakan teknik self-management (pengelolaan diri). Teknik ini akan lebih efektif melalui pemberian layanan konseling individu. Karena Teknik ini merupakan teknik yang dapat merubah perilaku seseorang untuk menghilangkan kebiasaan buruk contohnya seperti: malas belajar, suka bolos, suka membuli, boros, keluar masuk saat jam pelajaran berlangsung dll. Teknik ini dimaksudkan untuk meningkatkan kepekaan klien agar mengamati respon pada stimulus yang disenanginya dengan kebalikan stimulus tersebut.

Dengan demikian konseling individu menggunakan teknik self-management memberikan kontribusi yang penting dalam memotivasi siswa, dalam masalah kebiasaan belajar daring saat ini merupakan masalah yang banyak dialami oleh peserta didik sehingga untuk efisiensi waktu konseling individu dimungkinkan lebih efektif dibandingkan layanan konseling individual. 
Jurnal HELPER, Vol 36 No 1 (2019) 07 - 15

Bimbingan dan Konseling Universitas PGRI Adi Buana Surabaya

ISSN: 02162938

Indikator manajemen waktu menurut Mandura (Meilistika, 2011:27) membagi manajemen waktu menjadi lima indikator, yaitu mampu menyusun tujuan, mampu menyusun prioritas, mampu membuat jadwal, mampu meminimalisir gangguan, mampu mendelegasikan tugas. Sedangkan menurut Haynes (2010:25) indikator manajemen waktu yang baik adalah membina

tanggung jawab, prioritas, sasaran, menyingkirkan aktivitas yang tidak penting dan tidak tepat serta merencanakan dan menjadwalkan penggunaan waktu setiap minggu dan hari.

\section{METODOLOGI}

Penelitian ini menggunakan jenis penelitian tindakan kelas (classroom action research). Alur kerja penelitian tindakan kelas menurut Kemmis dan Mc. Taggart dalam Arikunto (2006:97), alur penelitian itu terdiri dari empat kegiatan pokok, yaitu perencanaan (planning), tindakan (action) dan observasi (observe), serta refleksi (reflect). Penelitian ini dilaksanakan di SMK PGRI 2 Jombang, dengan menggunakan single subject yaitu siswa kelas XII TKJ yang memiliki permasalahan sulit mengatur waktu sehingga tidak bisa menyelesaikan pembelajaran daring dengan baik.

Penelitian ini dilakukan dalam 2 siklus dan masing-masing siklus dilaksanakan dalam 4 tahap yaitu tahap perencanaan, pelaksanaaan, pengamatan (observasi) dan refleksi:

1. Perencanaan

Pada tahap ini langkah-langkahnya sebagai berikut: a) Menyusun RPLBK, b)
Menyiapkan media layanan, c) Menyiapkan LKPD, d) Menyiapkan lembar evaluasi (proses dan hasil)

2. Pelaksanaan

Pelaksanaan dibagi menjadi 4 tahap yaitu tahap awal, tahap transisi, tahap inti, dan tahap penutup

3. Observasi (Pengamatan)

Observasi dilakukan untuk mengumpulkan informasi tentang proses layanan yang dilakukan peneliti sesuai dengan tindakan yang telah disusun. Melalui observasi peneliti dapat mencatat berbagai kelemahan dan kekuatan yang dilakukan guru dalam melaksanakan tindakan, sehingga hasilnya dapat dijadikan masukan ketika peneliti melakukan refleksi untuk penyusunan rencana pada siklus berikutnya. Pengamatan dilakukan oleh guru BK yang dibantu oleh teman sejawat sebagai observer selama proses kegiatan konseling individu berlangsung.

4. Refleksi

Refleksi adalah aktivitas melihat berbagai kekurangan yang dilaksanakan peneliti selama tindakan. Refleksi dilakukan dengan melakukan diskusi dengan observer oleh teman sejawat. Setelah melakukan proses layanan bimbingan konseling, apakah masih ditemukan kekurangan dari segi peneliti maupun yang diteliti.

\section{HASIL}

\section{Deskripsi Tahap Studi Awal}

Layanan konseling individu dengan selfmanagement akan diberikan kepada Ananda AISYAH (inisial) kelas XII TKJ. Pemberian 
Jurnal HELPER, Vol 36 No 1 (2019) 07 - 15

Bimbingan dan Konseling Universitas PGRI Adi Buana Surabaya

ISSN: 02162938

layanan konseling individu, disini peneliti menjelaskan prosedur yang harus diikuti oleh peserta didik. Diharapkan agar peserta didik dapat mengikuti prosedur layanan konseling individu mulai dari tahap awal sampai penutup. Peneliti juga berkolaborasi dengan teman sejawat sebagai observer dalam kegiatan layanan yang dilakukan. Yang hasilnya digunakan sebagai bahan pertimbangan perbaikan pemberian layanan konseling individu berikutnya. Sebelum melakukan konseling, konselor memberikan skala pengukuran yang terdiri dari beberapa item pertanyaan untuk mengetahui tingkat tanggung jawab belajar daring siswa.

\section{Pelaksanaan Penelitian Siklus I}

1) Perencanaan

Untuk mengoptimalkan pelaksanaan layanan, maka disusun perencanaan sebagai berikut:

a) Menyusun RPLBK

b) Menyiapkan media layanan

c) Menyiapkan LKPD

d) Menyiapkan evaluasi (proses dan hasil)

e) Menyusun skala pengukuran

\section{2) Pelaksanaan}

Siklus I dilaksanakan pada hari sabtu tanggal 17 Oktober 2020 yang dilakukan secara daring melalui aplikasi zoom meeting dengan link link http://gg.gg/Zoom1 tyas selama 30 menit. Yang dilakukan pada pukul 10.00-10.30 WIB Untuk melakukan konseling individu. Kegiatan layanan konseling individu terbagi dalam tahap awal, transisi, inti, dan penutup. Pada siklus I kegiatan layanan berjalan kurang lancar karena terkendala jaringan sehingga peserta didik/konseli kurang mendengar instruksi dari guru BK, selain kendala jaringan juga pada saat proses konseling peserta didik masih terlihat kaku dan kurang terbuka.

\section{3) Observasi (Pengamatan)}

Berdasarkan hasil observasi secara keseluruhan pelaksanaan layanan konseling individu dengan menggunakan teknik selfmanagement diperoleh catatan bahwa pada siklus I kegiatan layanan berjalan kurang lancar karena sempat terputus karena terkendala jaringan pada proses layanan, peserta didik/konseli kurang terbuka dan terlihat kaku saat menynceritakan permasalahnya. Hal ini mengakibatkan hasil yang diperoleh kurang maksimal dimana peserta didik masih merasa bingung dalam menyusun jadwal kegiatan yang disusun yang ditugaskan oleh peneliti.

a. Observasi Pelaksanaan Tindakan

Dari hasil observasi yang dilakukan oleh teman sejawat, dalam proses pelaksanaan layanan konseling masih ada yang perlu diperbaiki. Dalam proses penggalian masalah masih kurang mendalam dan juga masih ada tahapan dalam proses konseling individu yang belum dilakukan oleh peneliti.

b. Hasil Pemberian Tindakan 
Jurnal HELPER, Vol 36 No 1 (2019) 07 - 15

Bimbingan dan Konseling Universitas PGRI Adi Buana Surabaya

ISSN: 02162938

Untuk melihat ada tidaknya perubahan dalam tanggung jawab belajar daring peserta didik/konseli, peneliti memberikan skala pengukuran terhadap peserta didik yang menjadi subjek penelitian. Setelah dilakukan konseling individu dengan teknik self-management tentang tanggung jawab belajar, siswa mendapatkan skor 30\% artinya tanggung jawab belajar daring siswa masih rendah. Sehingga belum mencapai hasil yang diharapkan. Untuk itu perlu dilanjutkan ke kegiatan siklus II.

4) Refleksi

Refleksi dilaksanakan setelah tahapan observasi atau pengamatan dilakukan baik terhadap proses pelaksanaan tindakan maupun hasil pemberian tindakan. Hasil pengamatan dilakukan baik terhadap proses pelaksanaan tindakan menjadi salah satu bahan analisis. Selain itu data yang diperoleh melalui skala pengukuran untuk melihat perubahan yang terjadi setelah pemberian tindakan juga menjadi bahan analisis dalam kegiatan refleksi.

Kegiatan refleksi dilaksanakan pada tanggal 18 Oktober 2020 yang dilaksanakan di ruang BK dihadiri oleh peneliti dan teman sejawat sebagai observer. Berikut ini merupakan hasil pembahasan analisis terhadap data yang ada baik dari proses maupun hasil pemberian tindakan bimbingan dan konseling.

a. Aktivitas konselor (peneliti) dalam pelaksanaan konseling individu dapat dikategorikan baik. Tetapi karena kendala sinyal, membuat peserta didik sulit menangkap dan memahami apa yang disampaikan guru BK (peneliti). Dan juga ada tahapan yang belum dilakukan oleh guru BK (peneliti). Sehingga perlu diperbaiki agar proses konseling bisa dilakukan dengan baik dan tujuan dari konseling bisa sesuai dengan harapan.

b. Hasil skala pengukuran terhadap tanggung jawab belajar daring peserta didik/konseli , berdasarkan data hasil pengolahan menunjukkan pemberian tindakan pada siklus I masih belum mampu meningkatkan tanggung jawab belajar daring dengan skor 30 masih dalam katagori rendah. Karena dalam awal proses konseling konseling masih nampak kaku dan bingung. Selain itu kendala sinyal yang membuat komunikasi kurang lancar.

Agar hasil yang diperoleh lebih maksimal dan tanggung jawab peserta didik menunjukkan perubahan yang signifikan maka akan direncanakan siklus II, yang dilakukan secara daring dan dengan menerapkan tahapan konseling individu dengan teknik selfmanagement dengan lebih lengkap. Diharapkan siswa dapat menyelesaikan masalahnya dengan ditandai peingkatan tanggung jawab belajar daring yang signifikan.

\section{Pelaksanaan Penelitian Siklus II}

1) Perencanaan 
Jurnal HELPER, Vol 36 No 1 (2019) 07 - 15

Bimbingan dan Konseling Universitas PGRI Adi Buana Surabaya

ISSN: 02162938

Perencanaan pelaksanaan penelitian tindakan bimbingan dan konseling pada siklus II mengacu pada hasil pelaksanaan layanan siklus I. Beberapa kegiatan yang termuat dalam tahap perencanaan meliputi:

a) Menyusun RPLBK

b) Menyiapkan media layanan

c) Menyiapkan LKPD

d) Menyusun pedoman observasi atau pengamatan

e) Menyusun skala pengukuran. Digunakan untuk mengumpulkan data dari siswa mengenai perubahan yang terjadi setelah pemberian konseling individu pada siklus II.

f) Pemberian layanan konseling individu pada siklus II ini peneliti menggunakan langkah-langkah relaksasi yang telah direvisi berbeda dari siklus I.

2) Pelaksanaan

Siklus II dilaksanakan pada hari sabtu tanggal 24 Oktober 2020 yang dilakukan secara daring melalui aplikasi zoom meeting dengan http://bit.ly/zoomsiklus Tyas selama 30 menit. Yang dilakukan pada pukul 13.00-13.30 WIB. Pada siklus II kegiatan layanan berjalan lancar, siswa terlibat aktif dalam kegiatan layanan, siswa lebih antusias menerapkan teknik selfmanagement. Jaringan juga mendukung, sehingga intruksi yang disampaikan oleh guru BK (peneliti) dapat terdengar jelas oleh siswa, sehingga hasilnya dapat lebih maksimal Hasil skala pengukuran siklus II siswa mendapatkan skor 70 yang artinya masuk dalam kategori sedang, artinya siswa/konseli bisa meningkatkan tanggung jawab. Akan tetapi pemantauan yang dilakukan tetap dilakukan sampai peserta didik bisa mendapatkan skor yang baik, artinya konseli benar-benar bisa menyelesaikan masalahnya dengan baik dan konsisten dalam melaksanakan kegiatan yang sudah disusun. Kegiatan layanan konseling individu terbagi dalam tahap awal, transisi, inti, dan penutup. Tidak lupa, rekan sejawat(observer) membawa lembar penilaian yang nantinya akan dibuat sebagai laporan kegiatan pada siklus II.

3) Observasi

a. Proses Pelaksanaan Tindakan

Hasil pengamatan teman sejawat terhadap pelaksanaan tindakan bimbingan konseling. Dalam pertemuan ini aktivitas guru BK (peneliti) mengalami peningkatan dari kategori baik menjadi sangat baik. Dan pada pertemuan ini adanya kepuasan baik guru BK (peneliti) maupun peserta didik (konseli). 
Jurnal HELPER, Vol 36 No 1 (2019) 07 - 15

Bimbingan dan Konseling Universitas PGRI Adi Buana Surabaya

ISSN: 02162938

Berdasarkan hasil observasi secara keseluruhan pelaksanaan layanan konseling individu dengan menggunakan teknik self-management diperoleh catatan bahwa pada siklus II kegiatan layanan berjalan lancar, siswa terlibat aktif dalam kegiatan layanan, siswa juga antusias menerapkan teknik selfmanagement. Jaringan juga mendukung, sehingga suara guru BK(peneliti) dapat terdengar jelas. Selain itu siswa juga lebih terlibat aktif dalam menentukan penerapan teknik, membuat jadwal kegiatan dan juga Tanya jawab dalam proses konseling, sehingga hasilnya dapat lebih maksimal. Pada siklus II ini terjadi peningkatan tanggung jawab dalam belajar daring, dari skor 30 (rendah) menjadi 70 (sedang).

b. Dampak Pelaksanaan Tindakan

Dampak positif pemberian tindakan melalui penerapan konseling individu dengan menggunakan strategi relaksasi dapat mereduksi stres dalam belajar siswa. Hal ini dapat terlihat dari data hasil skala pengukuran terhadap siswa yang menjadi subjek penelitian. Dapat dilihat dari tabel berikut ini:

\begin{tabular}{|l|l|l|}
\hline Keterangan & Skor & Kategori \\
\hline Pra Siklus & 25 & Rendah \\
\hline Siklus I & 30 & Rendah \\
\hline Siklus II & 70 & Sedang \\
\hline
\end{tabular}

4) Refleksi
Kegiatan refleksi siklus II dilaksanakan pada tanggal 24 Oktober 2020 di ruang bimbingan dan konseling SMK PGRI 2 Jombang dan dibantu oleh teman sejawat selaku observer. Setelah mencermati, mengkaji dan menganalisis data yang ada, maka peneliti dan teman sejawat dapat diuraikan sebagai berikut:

a. Aktivitas guru BK/konselor dan siswa secara umum mencapai kategori sangat baik, dan adanya pemahaman bagaimana penerapan teknik self-management yang tinggi dengan meningkatkan tanggung jawab belajar daring peserta didik (konseli), dan rasa puas baik peserta didik maupun guru BK (peneliti).

b. Pelaksanaan tindakan melalui konseling individu dengan teknik self-management telah membawa perubahan yang positif dengan meningkatkan tanggung jawab belajar daring peserta didik(konseli). Data penelitian siklus II menunjukan, tingkat tanggung jawab belajar daring siswa meningkat mencapai skor 70 atau dalam kategori sedang. Hal ini menunjukkan bahwa permasalahan siswa dapat terselesaikan dengan ditandai dengan peningkatan tanggung jawab belajar daring siswa yang yang signifikan, dan juga informasi yang diterima dari guru mata pelajaran yang melaporkan bahwa peserta didik(konseli) mulai aktif mengikuti pembelajaran daring. Oleh karena itu penelitian tindakan bimbingan dan konseling dalam upaya meningkatkan tanggung jawab belajar daring peserta 
Jurnal HELPER, Vol 36 No 1 (2019) 07 - 15

Bimbingan dan Konseling Universitas PGRI Adi Buana Surabaya

ISSN: 02162938

didik(konseli) kelas XII TKJ di SMK

PGRI 2 Jombang dianggap cukup dan tidak perlu dilanjutkan ke siklus berikutnya karena dalam teknik selfmanagement terus bisa dipantau perubahan perilakunya.

\section{Pembahasan Dalam Penelitian}

Penerapan konseling individu dalam penelitian tindakan bimbingan dan konseling merupakan upaya membantu siswa dalam menyelesaikan masalah yang berhubungan dengan tagging jawab belajar daring. Penelitian tindakan bimbingan dan konseling yang dilakukan melalui 2 siklus ini dilakukan untuk mengetahui sejauh mana tanggung jawab belajar daring siswa dengan menggunakan layanan konseling individu dengan teknik self-management siswa kelas XII TKJ SMK PGRI 2 Jombang. Adapun perubahan tingkah laku peserta didik bisa dilihat pada grafik sebagai berikut:

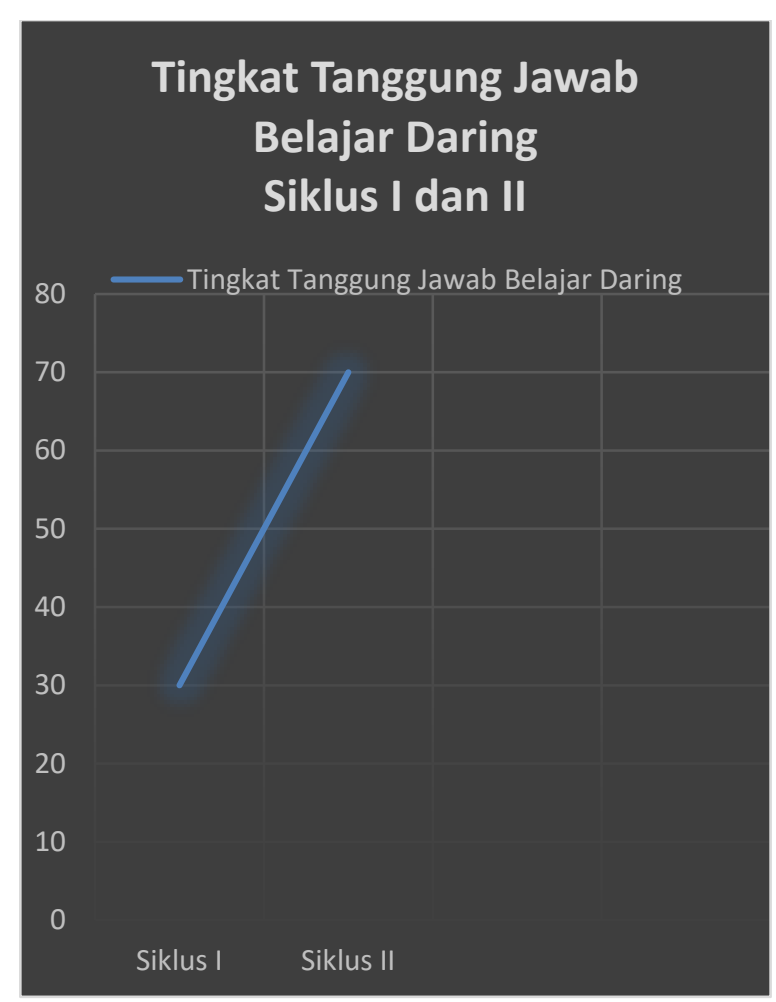

Dari data pada grafik diatas, maka dapat dilihat peningkatan tanggung jawab belajar daring siswa, pada siklus I menjadi 30 kategori rendah, dan pada siklus II menjadi 70 kategori sedang.

\section{KESIMPULAN}

Dari hasil analisis dapat disimpulkan bahwa ada perubahan tingkah laku siswa. Hal ini dapat dilihat dari peningkataan skor tanggung jawab belajar daring siswa. Pada siklus I skor 30 artinya tanggung jawab belajar siswa masih rendah. Kemudian pada siklus II meningkat menjadi 70 dengan katagori sedang. Dengan demikian dapat disimpulkan bahwa teknik selfmanagement dapat meningkatkan tanggung jawab belajar daring siswa kelas XI TKJ SMK PGRI 2 Jombang tahun ajaran 2020/2021. 
Jurnal HELPER, Vol 36 No 1 (2019) 07 - 15

Bimbingan dan Konseling Universitas PGRI Adi Buana Surabaya

ISSN: 02162938

\section{SARAN}

Berdasarkan kajian teoritis dan hasil penelitian, ada beberapa saran yang yang akan peneliti kemukakan:

1. Agar penyelenggaran program bimbingan dan konseling mencapai hasil yang optimal dibutuhkan inovasi secara terus menerus sesuai dengan kebutuhan dan perkembangan jaman.

2. Dalam melaksanakan kegiatan layanan bimbingan konseling hendaknya guru BK mengetahui karakteristik kebutuhan peserta didik dan lingkungan, tahapan-tahapan layanan konseling, konsep awal siswa, serta alat atau media yang digunakan sesuai dengan kebutuhan.

3. Dalam setiap kegiatan layanan bimbingan konseling hendaknya guru melibatkan peserta didik secara aktif, agar ikut serta dalam memecahkan permasalahan yang dihadapi.

4. Guru BK hendaknya mau mencoba untuk mencari teknik atau metode layanan bimbingan konseling yang kreatif, inovatif dan tidak konvensional.

\section{DAFTAR PUSTAKA}

Abidin, Zainal. (2009). Optimalisasi Konseling Individu Dan Kelompok Untuk Keberhasilan Siswa. Jurnal Pemikiran Alternatif Pendidikan.
Arikunto, Suharsimi. 2006. Prosedur Penelitian Suatu Pendekatan Praktek, Jakarta: Rineka Cipta.

Dewi, Febrina Putri. 2016. Tingkat Tanggung Jawab Belajar Siswa Kelas VIII SMP Negeri 13 Yogjakarta Tahun Ajaran 2015/2016 dan Implikasinya Terhadap Usulan Topik-topik Bimbingan Belajar, (Online),

(http://respository.usd.ac.id/6902/2/111 114002_full.pdf, diakses 9 November 2017).

Haynes, E Marion. 2010. Manajemen waktu (Edisi ketiga, Buku dari Seri Crips Fifty- ). Jakarta : Indeks.

Paixaluddin \& Ermalinda. 2016. Penelitian Tindakan kelas. Bandung: Alfabeta.

Ratna, Lilis. 2013. Teknik-teknik Konseling. Sleman: Deeplublish.

Walgito, Bimo. (2010). Bimbingan dan Konseling. Yogyakarta: Yayasan Penerbit Fakultas Psikologi UGM. 